\title{
DEVELOPMENT OF TERMINALIA CHEBULA LOADED ETHOSOMAL GEL FOR TRANSDERMAL DRUG DELIVERY
}

\author{
FATIMA GRACE $\mathrm{X}^{*}$, SUGANYA $\mathrm{K}$, SHANMUGANATHAN S
}

Department of Pharmaceutics, Faculty of Pharmacy, Sri Ramachandra Medical College and Research Institute, Porur, Chennai - 600 116, Tamil Nadu, India. Email: santagracek@gmail.com

Received: 16 June 2018, Revised and Accepted: 09 August 2018

\begin{abstract}
Objective: Oral route is the usual route of drug delivery which has many advantages such as easy delivery but has disadvantages such as poor bioavailability and tendency to produce rapid blood level spikes, such that there becomes a necessity for higher dose or recurrent dosing which becomes difficult for the patient and also high cost. Keeping all these drawbacks in concern, there arises a necessity for novel development of drug delivery with improved therapeutic efficacy and safety with targeted delivery such that size and number of doses could be reduced. This can be achieved by transdermal delivery which possesses several advantages such as avoids first-pass metabolism, eliminates gastrointestinal irritation reduces frequency of dosing, and rapid termination of drug action.
\end{abstract}

Methods: Dried fruits of Terminalia chebula were extracted and preliminary phytochemical evaluation was performed. Ethosome was prepared by cold method using soya lecithin. Ethosomal gel was prepared using carbopol as gelling agent and was evaluated.

Results and Discussion: The prepared gel was evaluated for its pharmaceutical properties and was found to be satisfactory. The in vitro drug diffusion of ethosomal gel showed better release compared with that of the gel with extract. In vitro anti-arthritic activity exhibited significant effect compared to that of the standard diclofenac.

Conclusion: Considering all the above-mentioned factors, the present study was aimed to develop a natural drug-loaded ethosomal gel for transdermal drug delivery, thereby permeation of drug can be enhanced compared with conventional dosage forms.

Keywords: Ethosomal, Gel, Terminalia chebula, Ethanol, Transdermal delivery drug.

(C) 2018 The Authors. Published by Innovare Academic Sciences Pvt Ltd. This is an open access article under the CC BY license (http://creativecommons. org/licenses/by/4. 0/) DOI: http://dx.doi.org/10.22159/ajpcr.2018.v11i12.20764

\section{INTRODUCTION}

Skin is made of three main layers such as subcutaneous layer, dermis, and epidermis. Drugs mainly penetrate at the intercellular spaces or the lipid bilayers [1]. There are numerous advantages in developing a transdermal formulation such as follows:

- Avoid first-pass metabolism

- Avoids risk and inconveniences of parenteral therapy

- Substitutes oral when is unsuitable as in case of vomiting, etc.

- Avoids vagaries that occur with GI absorption due to $\mathrm{pH}$, enzymatic activity, and drug-food interactions

- Reduces daily dosing

- Improves patient compliance

- Rapid termination of drug

- Suitability of self-administration [2,3]

Although with all these advantages, targeted drug delivery faces few disadvantages such as follows:

- Difficulty in drug permeation through skin

- Skin irritation

- Clinical need.

To overcome these difficulties [4,5], a novel transdermal dosage form with improved permeation can be developed, i.e., ethosomal drug delivery which has phospholipids, water, and ethanol in high concentration, thus increases skin permeation of the drug. Delivery of drug by ethosome is assumed by two reasons one being ethanol which is basically a permeation enhancer acts by decreasing the density of lipid multilayer by penetrating into intercellular lipid therapy increasing the fluidity of the lipid cell membrane and the others by ethosome which can easily permeate into the deep layer of the skin when combined with the lipids, thus releasing the drug into the deep layers of the skin [6-8].

Since ancient times, it is believed that herbal drugs are safe with no adverse effects. Thus, the present work is to develop an herbal ethosome using Terminalia chebula extract.

T. chebula is a deciduous tree belonging to the family Combretaceae, commonly called as Kadukkai, Haritaki, and Myrobalan. Leaves, seeds, bark, and fruit are used medicinally as astringents, purgative, stomachic, and laxative and also used in inflammation, anthelmintic, cardiotonic, aphrodisiac, digestion, etc. [9-11].

\section{METHODS}

Fruits of T. chebula were procured from local market, were dried powered and stored for further use.

\section{Preparation of extract}

T. chebula extract was prepared by cold maceration process with 70:30 ethanol: water for $72 \mathrm{~h}$.

\section{Preliminary phytochemical studies}

The extract was tested for flavonoids (Shinado's test), anthraquinones (Borntrager's test), glycosides, carbohydrates, alkaloids (Dragendorff's and Mayer's), quinines, phenols, tannins, saponins, proteins, and amino acids [12]

\section{Formulation of ethosomes}

T. chebula loaded ethosomes were prepared by cold method. Soya lecithin was accurately weighed and dissolved with required quantity 
of water separately. Drug and cholesterol were weighed and dissolved in required quantity of ethanol. This was then transferred little by little into the lecithin solution and was stirred vigorously to get a homogenous mixture. Propylene glycol was added and vigorously stirred. This solution was then sonicated/extruded to decrease the size of vesicle. This was then packed in glass vial and stored in refrigerator for further use [13-16] (Table 1)

\section{Preparation of ethosomal gel}

Methyl- and propyl-paraben were added to $50 \mathrm{ml}$ water and required quantity of carbopol was added little by little and dispersed homogenously. Propylene glycol and EDTA were added to the above mixture. To $25 \mathrm{ml}$ of water, triethanolamine was added to maintain the desired $\mathrm{pH}$. To the above gel, the prepared ethosomes was added and dispersed well to get the ethosomal gel [17-20] (Table 2).

\section{Evaluation of ethosomal gel} Spreadability

This was measured by slip and drug basis. Gel was sandwiched within the slides and $100 \mathrm{~g}$ weight was placed on the upper slide for $5 \mathrm{~min}$. The time taken to separate the two slides was noted.

Table 1: Formulation of ethosomes

\begin{tabular}{ll}
\hline Ingredients & Quantity (\%) \\
\hline Drug & 1 \\
Soya lecithin & 4 \\
Cholesterol & 0.5 \\
Ethanol & 45 \\
Propylene glycol & 20 \\
Water & Q.S. \\
\hline
\end{tabular}

Table 2: Preparation of ethosomal gel

\begin{tabular}{llll}
\hline S. No. & Ingredient & Ethosomal gel (\%) & Gel (\%) \\
\hline 1. & Ethosome & 1 & - \\
2. & T. chebula extract & - & 1 \\
3. & Carbopol & 2 & 2 \\
4. & Propylene glycol & 15 & 15 \\
5. & Sodium edentate & 0.01 & 0.01 \\
6. & Propylparaben & 0.001 & 0.001 \\
7. & Methylparaben & 0.05 & 0.05 \\
8. & Triethanolamine & Q.S. & Q.S. \\
9. & Water & Q.S. & Q.S. \\
\hline T. chebula & Terminalia chebula & &
\end{tabular}

Table 3: Preliminary phytochemical screening of T. chebula

\begin{tabular}{lll}
\hline S. No. & Phytochemicals & Inference \\
\hline 1 & Test for alkaloids & \\
& Dragendorff's test & ++ \\
& Mayer's test & ++ \\
2 & Test for flavonoids & \\
& Shinado's test & + \\
3 & Test for carbohydrates & ++ \\
& Fehling's test & + \\
4 & Test for glycosides & + \\
5 & Test for saponins & + \\
& Lead acetate test & + \\
7 & Test for tannins & + \\
& Lead acetate test & + \\
& Test for proteins and amino acid & + \\
& Ninhydrin test & + \\
\hline
\end{tabular}

+Present, T. chebula: Terminalia chebula

\section{Extrudability}

This was done using lacquered aluminum collapsible tube. Extrudability was determined by measuring the amount of the gel extruded through the tip when a constant weight was applied [21-23].

\section{In vitro drug diffusion}

This test was performed using an open-ended cylinder, of which one end was closed using a semipermeable membrane, and the sample was placed over it. The membrane was completely covered inside, and it was placed in the diffusion medium ( $\mathrm{pH} 7.4$ phosphate buffer) which, in turn, was placed on a magnetic stirrer with $37^{\circ} \mathrm{C} \pm 2^{\circ}$. Sample was withdrawn at a time interval of $30 \mathrm{~min}$ for $6 \mathrm{~h}$, and absorbance was measured at $272 \mathrm{~nm}$ [24-27].

\section{In vitro anti-arthritic activity}

In vitro anti-arthritic activity study was carried out based on protein denaturation method. Test solution was prepared with $0.45 \mathrm{ml}$ bovine serum albumin. $1 \mathrm{~N} \mathrm{HCl}$ was used to adjust the $\mathrm{pH}$ to 6.3 . The samples was then incubated at $37^{\circ} \mathrm{C}$ for $20 \mathrm{~min}$ and heated at $57^{\circ} \mathrm{C}$ for $3 \mathrm{~min} .2 .5 \mathrm{ml}$ of phosphate buffer $\mathrm{pH} 6.3$ was added to the cooled sample. Test control was prepared using distilled water with bovine serum albumin, and standard solution was prepared with $0.05 \mathrm{ml}$ of diclofenac sodium solution in various concentrations with bovine serum albumin, rest of the procedures of test control, and standard solution followed as similar as with test solution preparation [23,28-31].

The percentage inhibition of protein denaturation was calculated as follows:

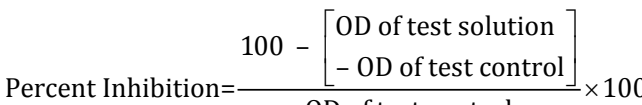

The control represents $100 \%$ protein denaturation. The result was then compared with diclofenac sodium.

\section{RESULTS AND DISCUSSION}

Preliminary phytochemical screening of $T$. chebula

The extract showed the presence of alkaloids, flavonoids, carbohydrate, saponins, tannins, quinones, proteins, and amino acids (Table 3)

Table 4: In vitro drug diffusion study

\begin{tabular}{llll}
\hline S. No. & Time (h) & Gel with 1\% extract & Ethosomal gel (\%) \\
\hline 1. & 0 & 0 & 0 \\
2. & 0.5 & 10.8 & 14.14 \\
3. & 1 & 13.96 & 22.41 \\
4. & 2 & 27.12 & 32.64 \\
5. & 4 & 35.92 & 41.82 \\
6. & 6 & 43.21 & 56.32 \\
\hline
\end{tabular}

Table 5: In vitro anti-arthritic activity of $T$. chebula extract

\begin{tabular}{llll}
\hline S. No. & Concentration $(\boldsymbol{\mu g} / \mathbf{m l})$ & \multicolumn{2}{l}{ Percentage inhibition } \\
\cline { 3 - 4 } & & $\begin{array}{l}\text { T. chebula } \\
\text { extract }\end{array}$ & $\begin{array}{l}\text { Diclofenac } \\
\text { sodium }\end{array}$ \\
\hline 1. & 10 & 21.221 & 22.17 \\
2. & 50 & 40.357 & 42.116 \\
3. & 100 & 57.256 & 53.886 \\
4. & 200 & 65.891 & 61.276 \\
5. & 400 & 72.131 & 67.43 \\
6. & 800 & 76.090 & 75.905 \\
7. & 1000 & 88.129 & 89.39 \\
\hline T. & & &
\end{tabular}




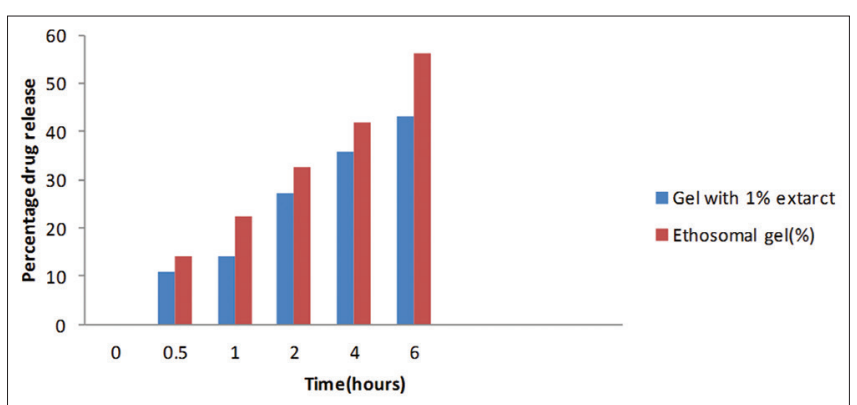

Fig. 1: In vitro drug release

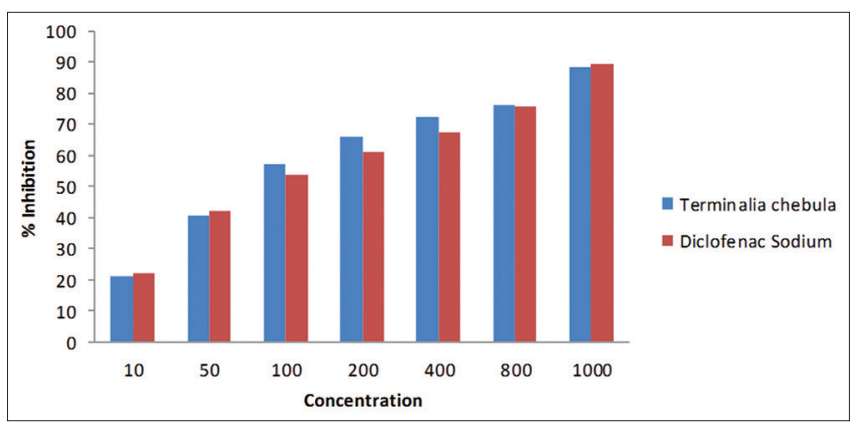

Fig 2: In vitro anti-arthritic activity of Terminalia chebula extract

\section{Evaluation of ethosomal gel}

$p H$ determination

The $\mathrm{pH}$ of the ethosomal formulation was in the range of 6.4.

\section{Spreadability studies}

The spreadability of the ethosomal formulation was found to be $44 \mathrm{~mm}$.

\section{Rheological studies}

The viscosity of the ethosomal formulation was found to be $4700 \mathrm{cps}$ using Ostwald's viscometer.

\section{In vitro drug diffusion study}

The diffusion study showed that there was better permeation with the ethosomal gel than compared with that of the gel which contains extract (Table 4 and Fig 1).

\section{In vitro anti-arthritic activity of T. chebula extract}

The in vitro anti-arthritic potential of the T. chebula extract was performed using protein denaturation method. The results showed that the extract at different concentrations from 10 to $1000 \mu \mathrm{g} / \mathrm{ml}$ exhibited significant anti-arthritic activity compared to that of the standard drug (Table 5 and Fig 2).

\section{CONCLUSION}

Clinical efficacy is one of the most vital criteria for any novel drug delivery system. T. chebula is used for multiple actions given usually by oral route which has poor bioavailability making the treatment unsatisfactory. Thus, a novel ethosomal drug delivery has been developed with ease of self application and also with high permeability due to ethanol compared with conventional transdermal dosage forms. To conclude, the present work will have better permeability, thus better absorption and thereby increased bioavailability.

\section{ACKNOWLEDGMENT}

The authors are grateful to the management of Sri Ramachandra University, for providing all the facilities for the successful completion of the work.

\section{AUTHORS' CONTRIBUTION}

All the authors have equally contributed to the outcome of this work.

\section{CONFLICTS OF INTEREST}

The authors declare that they have no conflicts of interest.

\section{REFERENCES}

1. Dinesh D, Amit AR, Maria S, Awaroop RL, Mohd HG. Drug vehicle based approaches of penetration enhancement. Int J Pharm Pharm Sci 2009;1 Suppl 1:24-45.

2. Gangwar S, Singh S, Garg G. Ethosomes: A novel tool for drug delivery through the skin. J Pharm Res 2010;3 Suppl 4:688-91.

3. Rao Y, Zheng F, Zhang X, Gao J, Liang W. In vitro percutaneous permeation and skin accumulation of finasteride using vesicular ethosomal carriers. AAPS PharmSciTech 2008;9:860-5

4. Verma DD, Fahr A. Synergistic penetration enhancement effect of ethanol and phospholipids on the topical delivery of cyclosporin A. J Control Release 2004;97:55-66.

5. Kumar KP, Radhika PR, Sivakumar T. Ethosomes-a priority in transdermal drug delivery. Int J Adv Pharm Sci 2010;1:111-21.

6. Touitou E, Dayan N, Levi-Schaffer F, Piliponsky A. A novel lipid vesicular system for enhanced delivery. J Lip Res 1998;8:113.

7. Nikalje AP, Tiwari S. Ethosomes: A novel tool for transdermal drug delivery. Int J Res Pharm Sci 2012;2 Suppl 1:1-20.

8. Anitha PS, Ramkanth K, Sankari UM, Alagusundaram K, Gnanapraksah P, Devaki DR, et al. Ethosomes-a noninvasive vesicular carrier for transdermal drug delivery. Int J Rev Life Sci 2011;1 Suppl 1:17-24.

9. World Health Organization. Traditional Medicine-Growing Needs and Potential. WHO Policy Perspectives on Medicine. No. 2. WHO/ EBM/2002. Geneva: WHO; 2002.

10. CSIR. The wealth of India- A Dictionary of Indian Raw Materials and Industrial Products. Vol X. New Delhi: Publication and Information Directorate, CSIR; 2002. pp. 522-524.

11. Khandelwal KR. Practical Pharmacognosy Techniques and Experiments. 22 ed. Pune: Nirali Prakashan; 2012. p. 3.3-5.

12. Kokate CK, Purohit AP, Gokhale SB. Pharmacognosy. 48 ed. Pune: Nirali Prakashan; 2013. p. 7.4.

13. Patel S. Ethosomes: A promising tool for transdermal delivery of drug. Pharm Info Net 2007;5 Suppl 3:2007.

14. Sheer A, Chauhan M. Ethosomes as vesicular carrier for enhanced transdermal delivery of ketoconazole-formulation and evaluation. J Pharm Cosmetol 2011;1 Suppl 3:1-14.

15. Guy RH. Ethosomes and recent approach in transdermal drug delivery system. Int J Pharm 1985;6:112-6.

16. Panchagnula R, Pillai O, Nair VB, Ramarao P. Transdermal iontophoresis revisisted. Curr Opin Chem Bio 2000;4:468-73.

17. Mezei M, Gulasekharam V. Liposomes-a selective drug delivery system for the topical route of administration. Lotion dosage form. Life Sci 1980;26:1473-7.

18. Jain NK. Advances in Controlled and Novel Drug Delivery. $1^{\text {st }}$ ed. New Delhi: CBS Publication; 2001. p. 428-51.

19. Touitou E. Composition of Applying Active Substance to or Through the Skin. US: Patent; 1998. p. 5540934.

20. Barry BW. Is transdermal drug delivery research still important today? Drug Discov Today 2001;6:967-71.

21. Biju SS, Sushama T, Mishra PR, Khar RK. Vesicular systems: An overview. Ind J Pharm Sci 2006;68:141-53.

22. Lopez-Pinto J.M, Gonzalez-Rodriguez M.L, Rabasco A.M. Effect of cholesterol and ethanol on dermal delivery from DPPC liposomes. Int J Pharm 2005;298:1-12.

23. Jain S, Tiwary AK, Sapra B, Jain NK. Formulation and evaluation of ethosomes for transdermal delivery of lamivudine. AAPS PharmSciTech 2007;8:E111.

24. Sheo DM, Sunil KP, Anish KG, Gyanendra KS, Ram CD. Formulation development and evaluation of ethosome of stavudine. Ind J Pharm Edu Res 2010;44 Suppl 1:102-8.

25. Bendas ER, Tadros MI. Enhanced transdermal delivery of salbutamol sulfate via ethosomes. AAPS PharmSciTech 2007;8:E107.

26. Jain S, Jain NK. Progress in Controlled and Novel Drug Delivery System. New Delhi: CBS Publishers and Distributors; 2004. p. 131-53.

27. Patel NA, Patel NJ, Patel RP. Formulation and evaluation of curcumin gel for topical application. Pharm Dev Technol 2009;14:80-9. 
28. Garg A, Negi LM, Chauhan M. Gel containing ethosomal vesicles for transdermal delivery of aceclofenac. Int $\mathrm{J}$ Pharm Pharm Sci 2010;2 Suppl 2:102-8

29. Brahmankar DM, Jaiswal SB. Biopharmaceutics and Pharmacokinetics a Treatise. $1^{\text {st }}$ ed. New Delhi: Vallabh Prakashan; 2002. p. 337.
30. Chippada SC, Vangalapati M. Antioxidant, an anti-inflammatory and anti-arthritic activity of Centella asiatica extracts. J Chem Biol Phys Sci 2011;1 Suppl 2:260-9.

31. Pandey S. Various techniques for the evaluation of anti arthritic activity in animal models. J Adv Pharm Technol Res 2010;1:164-71. 